Огляди літератури, оригінальні дослідження, погляд на проблему, випадок з практики, короткі повідомлення УДК 616.126-006.327:616.126.52]-053.2-036.1-093:575

DOI 10.11603/1811-2471.2019.v.i3.10401

\title{
ЕКСПРЕСІЯ ГЕНУ NFАТС1 У ДІТЕЙ 3 ДВОСТУЛКОВИМ АОРТАЛЬНИМ КЛАПАНОМ СЕРЦЯ ЗАЛЕЖНО ВІД НАЯВНОСТІ КЛАПАННОГО ФІБРОЗУ
}

๑А. В. Каменщик

\section{Запорізький державний медичний університет}

РЕЗЮМЕ. Двостулковий аортальний клапан (ДАК) є частою вродженою вадою серця, що призводить до розвитку серйозних серцевих ускладнень. $Є$ відомості про протективну роль клітин імунної системи при розвитку фібротичних процесів у міокарді. Гени сімейства нуклеарного фактора активованих Т-клітин (NFATC), регулюючи транскрипційні реакції шляхом активації Са-залежного шляху кальциневрину, беруть участь як у вальвулогенезі, так і в імунній відповіді.

Мета - визначення величини відносної нормалізованої експресії NFATC1, параметрів клітинного імунітету, рівнів сироваткового кальцію при фіброзі стулок аортального клапана у дітей з ДАК та виявлення взаємозв'язків між зазначеними показниками.

Матеріал і методи. У 40 дітей з ДАК, у 18 з яких мав місце фіброз стулок клапана аорти, визначені параметри кровотоку на клапані, діаметр кореня аорти (Ао) і товщина задньої стінки лівого шлуночка (ЗСлш) й міжшлуночкової перегородки (МШП), рівень експресії NFATC1 (ехрNFATC1) методом екстракції РНК, абсолютний та відносний вміст CD95+ апоптоз регулюючої і CD25+- активованих інтерлейкін-2 рецепторнесучої субпопуляції лімфоцитів методом моноклональних антитіл, а також сироваткового кальцію (Са).

Результати. У дітей з ДАК при наявності фіброзу стулок клапана встановлено достовірне підвищення ехр NFATC1, збільшення Ао, Са, абсолютного вмісту CD25+, зменшення абсолютного і відносного вмісту CD95 $5^{+}$субпопопуляцій лімфоцитів. Встановлено прямі кореляції між еxpNFATC1 і Са, абсолютними значеннями CD25+ і CD95+ Т-клітин, що свідчило про важливу діагностичну роль ехрNFATC1 при розвитку фіброзу клапана у цієї категорії пацієнтів.

КЛючОВІ СлОВА: двостулковий аортальний клапан; діти; фіброз стулок; експресія гену NFATC1; кальцій; клітинний імунітет.

Вступ. Двостулковий аортальний клапан (ДАК) $\epsilon$ найчастішою вродженою вадою серця, що має популяційну частоту $1-2 \%$ [1]. За даними А. С. Шарикіна (2016) [2], ДАК слід розцінювати як серйозну серцеву ваду, що може призводити до розвитку стенозу або недостатності клапана та супроводжується розширенням кореня аорти 3 порушенням гемодинаміки, гіпертрофією лівого шлуночка та загрозою розшарування аорти, а не як малу аномалію серця, що не впливає на кровообіг, як вважали раніше, що потребує диспансерного спостереження за хворими, починаючи з раннього віку. За даними Е. Girdauskas та M. A. Borger, у дитячому віці перебіг вади здебільшого сприятливий, а клінічні прояви наявні у 1 з 10 обстежених пацієнтів. Більшість ускладнень виникає у віці від 30 до 40 років у зв'язку з розвитком дисфункції лівого шлуночка та критичною дилатацією аорти [3]. Також підкреслюється, що у осіб молодого віку з ДАК діаметр аорти збільшений, у деяких з них формується аневризма, а у дітей з ДАК дилатація висхідної аорти спостерігається у 74 \% випадків [4], причому рівень дилатації аорти не залежить від градієнта тиску на клапані [5]. За даними T. Niaz, J. T. Poterucha, J. N. Johnson, C. Craviari, T. Nienaber, J. Palfreeman та співавт., [6] не дивлячись на сприятливий та безсимптомний перебіг ДАК у дітей, тяжкість аор- тальної регургітації при збільшенні віку хворих поступово зростає. При цьому діти, що мають ДАК, у дорослому віці, порівняно з іншими хворими на ВВС, мають відносно вищу частоту раптової серцевої смерті [7]. Слід також зазначити, що у деяких дослідженнях підкреслюється, що нуклеарний фактор активованих Т-клітин 1 (NFATC1), який знаходиться у цитоплазмі та при взаємодії із зовнішніми сигнальними молекулами інтерналізується до ядра клітини, може бути активованим фактором росту судинного ендотелію (VEGF) та $\epsilon$ інтегральним регулятором транскрипційних механізмів ендотеліально - мезенхімних перетворень при вальвулогенезі, активує проліферативні процеси в ендокарді та сприяє кінцевій елонгації серцевих клапанів [8]. Водночас гени сімейства NFATC беруть участь у регуляції IL-2 залежної імунної відповіді [9]. Останніми дослідженнями також встановлено, що певні субпопуляції Т-клітин мають захисну функцію щодо розвитку фібротичних процесів у міокарді, а в експериментальних моделях доведена відновлювальна роль цих клітин при експериментальному міокардіальному фіброзі [10]. Експресія імунокомпетентних клітин встановлена також при патоморофологічних перетвореннях, пов'язаних із розвитком неопластичних процесів ендометрія [11]. Встановлена кальцифікація аортального клапана у дорос- 
Огляди літератури, оригінальні дослідження, погляд на проблему, випадок з практики, короткі повідомлення лих хворих з ДАК [12]. Було також виявлено, що у тварин з експериментальною серцевою недостатністю активація NFAT $є$ вторинною та відбувається у відповідь на перенавантаження Са ${ }^{2+}[13]$. У наших попередніх дослідженнях була встановлена наявність помірної гіпертрофії міокарда при значному збільшенні пікового градієнта тиску на аортальному клапані та гіперекспресії гену NFATC1 у дітей з ДАК, порівняно з умовно здоровими дітьми групи контролю [14].

Мета - встановлення рівня експресії гену NFATC1 у дітей з двостулковим аортальним клапаном серця при наявності фіброзу стулок клапана та визначення взаємозв'язків цього показника з вмістом NFATC1-асоційованих показників клітинного імунітету та сироваткового кальцію у дітей з ДАК.

Матеріал і методи дослідження. Дослідження проведено у 40 дітей з ДАК, які були поділені на 2 групи. До першої групи увійшли 18 дітей 3 ДАК, що мали фіброз стулок аортального клапана, до другої групи було включено 22 дитини 3 ДАК, які не мали фіброзу. Пацієнти вказаних груп не відрізнялися між собою за індексом маси тіла, гендерним розподілом та віком. Доплерографічне дослідження серця проводили за допомогою сканера "Medison - 8000» датчиком 2,5 МГц з визначенням пікового градієнта тиску та пікової швидкості кровотоку на аортальному клапані, а також діаметра аорти, товщини задньої стінки лівого шлуночка (ЗСЛШ) та міжшлуночкової перегородки (МШП) Наявність двостулкового клапана діагностували за наявності характерної його форми у вигляді відкритого «риб'ячого рота» у систолі з визначенням ступеня регургітації на клапані. Фіброз стулок аортального клапана у зазначених категорій дітей діагностували за наявності їх потовщення та рихлості ехосигналу. У всіх дітей досліджуваних груп відзначали мінімальну регургітацію на клапані, ознак серцевої недостатності не було. Визначення рівня відносної нормалізованої експресії гену NFATC1 (рівень експресії у здорових дітей приймали за 1 одиницю експресії) у клітинах крові у зазначених 2 груп пацієнтів проводили за допомогою виділення тотальної РНК з використанням набору «РНК-экстран» («Синтол», Росія). РНК виділяли відповідно протоколу до набору. Для визначення рівня експресії досліджуваного гену використовували ампліфікатор CFX96 ${ }^{\text {TM }}$ Real-Time PCR Detection Systems («Bio-Rad Laboratories, Inc.», CША) і набір реактивів Maxima SYBR Green/ROX qPCR Master Mix (2X) (Thermo Scientific, CША). При імунологічному дослідженні І рівня за допомогою методу моноклональних антитіл у крові пацієнтів проводили визначення відносних та абсолютних рівнів CD25+-інтерлейкін-2

рецепторнесучих активованих лімфоцитів та їх CD95+ субпопуляції. Сироваткові концентрації загального кальцію визначали за допомогою діагностичного набору Liquick Cor-Calcium (Польща) на біохімічному аналізаторі Mindray BS-200 (Китай). Статистичну обробку даних проводили з використанням статистичного пакета Statistica 13.0 Для оцінки достовірності розбіжностей між групами використовували непараметричний критерій Манна-Уїтні для невеликих вибірок. Варіабельність у рядах даних визначали за допомогою квартильного оцінювання. Для визначення взаємозв'язків між показниками проводили визначення кореляцій за Спірменом. Взаємозв'язок між параметрами вважали дуже слабким при значенні коефіцієнта кореляції від 0 до 0,3, слабкимвід 0,3 до 0,5, середньої потужності - від 0,5 до 0,7, високої потужності - від 0,7 до 0,9 та надпотужним при значенні від 0,9 до 1,0.

Результати й обговорення. На першому етапі дослідження були проаналізовані основні гемодинамічні та морфометричні параметри у зазначених групах дітей з ДАК. Дані щодо основних доплерехокардіографічних показників у дітей залежно від наявності фіброзу стулок клапана наведені у таблиці 1. Як видно з даних, наведених у цій таблиці, у дітей з ДАК, що мали фіброз, був достовірно збільшений діаметр кореня аорти (Ме=25 мм ((Q25=23 мм; Q75=26 мм) та $\mathrm{Me}=20$ мм ((Q25=20 мм; Q75=24 мм), відповідно, p<0,05), при цьому піковий градієнт тиску на аортальному клапані (Ао к. гр.) у дітей з ДАК, залишаючись підвищеним у обох групах пацієнтів, був достовірно нижчим у дітей, що мали фіброз стулок клапана фіброзом (Ме=7,0 мм рт. ст. (Q25=2,89 мм рт. ст.; Q75=15,09 мм рт ст.) та $\mathrm{Me}=13,20$ мм (Q25=7,33 мм рт. ст.; Q75=36,04 мм рт ст.) відповідно р<0,05). Подібна спрямованість гемодинаміки на клапані стосувалася також і пікової швидкості кровотоку (Ме=1,12 м/с $((\mathrm{Q} 25=0,81 \mathrm{M} / \mathrm{c} ; \mathrm{Q} 75=2,0 \mathrm{M} / \mathrm{c})$ та $\mathrm{Me}=1,94 \mathrm{M} / \mathrm{c}$ ((Q25=1,39 м/с; Q75=3,21 м/с) відповідно, $\mathrm{p<0,05).}$ Водночас за даними доплерехокардіографії у зазначених двох групах дітей не було отримано достовірних розбіжностей, як за товщиною міжшлуночкової перегородки (Ме=8,5 мм (Q25=6,5 мм; $\mathrm{Q} 75=10,5 \mathrm{Mм})$ та $\mathrm{Me}=7,7$ мм (Q25=6,0 мм; Q75=8,3 мм), відповідно $\mathrm{p}<0,05)$, так і задньої стінки лівого шлуночка ( $\mathrm{Me}=8,5 \mathrm{MM}(\mathrm{Q} 25=7,0 \mathrm{MM}$; $\mathrm{Q} 75=10,5$ мм) та $\mathrm{Me}=7,0$ мм (Q25=7,0 мм; Q75=11,0 мм) відповідно $\mathrm{p}<0,05)$.

При фіброзі стулок клапана у дітей з ДАК, порівняно з тими, що не мали фібротичних змін на клапані, виявлено збільшення діаметра кореня аорти, при цьому значного зростання волюметричних показників на аортальному клапані не відбувалося. 
Огляди літератури, оригінальні дослідження, погляд на проблему, випадок з практики, короткі повідомлення Таблиця 1. Морфофункціональні показники еходоплерографії (Mе, (Q25; Q75)) у дітей з ДАК залежно від наявності фіброзу стулок

\begin{tabular}{|l|c|c|}
\hline \multicolumn{1}{|c|}{ Параметри гемодинаміки } & $\begin{array}{c}\text { Діти з ДАК, що мають } \\
\text { фіброз стулок } \\
(\mathrm{n}=18)\end{array}$ & $\begin{array}{c}\text { Діти з ДАК без фіброзу } \\
\text { стулок } \\
(\mathrm{n}=22)\end{array}$ \\
\hline Діаметр аорти, мм & $\begin{array}{c}25 \\
20^{*} \\
(20 ; 24)\end{array}$ \\
\hline Товщина міжшлуночкової перегородки, мм & $(23 ; 26)$ & 7,70 \\
& 8,5 & $(6,0 ; 8,3)$ \\
\hline Товщина задньої стінки лівого шлуночка, мм & $(6,5 ; 10,5)$ & 7,0 \\
& 8,5 & $(7,0 ; 11,0)$ \\
\hline Пікова швидкість кровотоку на аортальному клапані, м/с & $1,0 ; 10,5)$ & $1,94^{*}$ \\
\hline Піковий градієнт тиску на аортальному клапані, мм рт. ст. & $(1,39 ; 3,21)$ \\
\hline
\end{tabular}

Примітки: 1. * - p<0,05;

2. Q25; Q75 - верхній та нижній квартилі.

3 метою встановлення інших чинників розвитку фіброзу стулок у дітей з ДАК на наступному етапі дослідження було проведено визначення відносної нормалізованої експресії гену NFATC1, а також пов'язаних з його функцією показників клітинного імунітету та рівнів сироваткового кальцію (табл. 2).

Таблиця 2. Показники експресії гену NFATC1 та асоційованих показників клітинного імунітету й сироваткового кальцію (Ме, (Q25; Q75)) у дітей з ДАК залежно від наявності фіброзу стулок

\begin{tabular}{|c|c|c|}
\hline Параметри гемодинаміки & $\begin{array}{c}\text { Діти з ДАК, що мають } \\
\text { фіброз стулок } \\
(\mathrm{n}=18) \\
\end{array}$ & $\begin{array}{c}\text { Діти з ДАК без фіброзу } \\
\text { стулок } \\
(\mathrm{n}=22) \\
\end{array}$ \\
\hline NFATC1, ум. од & $\begin{array}{c}86,02 \\
(15,53 ; 106,51)\end{array}$ & $\begin{array}{c}14,53^{*} \\
(2,38 ; 63,07) \\
\end{array}$ \\
\hline $\mathrm{CD}_{25} 5^{+} \times 10^{9} / л$ & $\begin{array}{c}0,69 \\
(0,65 ; 0,75)\end{array}$ & $\begin{array}{c}0,45^{*} \\
(0,45 ; 0,57)\end{array}$ \\
\hline $\mathrm{CD}_{25} 5^{+}, \%$ & $\begin{array}{c}25 \\
(23 ; 26)\end{array}$ & $\begin{array}{c}26 \\
(25 ; 27)\end{array}$ \\
\hline $\mathrm{CD} 5^{+} \times 10^{9} / л$ & $\begin{array}{c}0,51 \\
(0,32 ; 0,76) \\
\end{array}$ & $\begin{array}{c}0,76^{*} \\
(0,57 ; 0,80) \\
\end{array}$ \\
\hline $\mathrm{CD}^{\circ} 5^{+}, \%$ & $\begin{array}{c}23,50 \\
(18,0 ; 28,0)\end{array}$ & $\begin{array}{c}32,0 * \\
(30,0 ; 33,0)\end{array}$ \\
\hline Сироватковий кальцій, ммоль/л & $\begin{array}{c}2,52 \\
(1,96 ; 2,60)\end{array}$ & $\begin{array}{c}2,36^{*} \\
(2,21 ; 2,57)\end{array}$ \\
\hline
\end{tabular}

Примітки: 1. * - p<0,05;

2. Q25; Q75 - верхній та нижній квартилі.

Як видно з даних, наведених у таблиці 2, при фіброзі стулок клапану у дітей з ДАК спостерігалося достовірне підвищення відносної нормалізованої експресії гену NFATC1 (Mе=86,02 од. (Q25=15,53 од.; $\mathrm{Q} 75=106,51$ од.) та $\mathrm{Me}=14,53 \mathrm{мм}$ (Q25=2,8 мм рт. ст.; Q75=63,07 мм рт ст.), відповідно $\mathrm{p}<0,05)$, що супроводжувалося також достовірним збільшенням абсолютної кількості CD25+інтерлейкін-2 рецепторонесучих активованих лім-

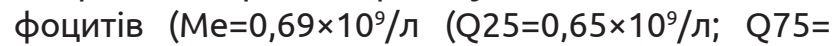
$0,75 \times 10^{9} /$ л) та $\mathrm{Me}=0,45 \times 10^{9} / л \quad\left(\mathrm{Q} 25=0,45 \times 10^{9} /\right.$; $\left.\mathrm{Q} 75=0,57 \times 10^{9} / л\right)$, відповідно $\left.\mathrm{p}<0,05\right)$. У той же час, у дітей з ДАК, що мали фіброз стулок клапана, спостерігали зниження як абсолютної, так й відносної кількості CD95+ субпопуляції лімфоцитів (Me $=0,51 \times 10^{9} /$ л $\left(\mathrm{Q} 25=0,32 \times 10^{9} /\right.$ л; $\mathrm{Q} 75=0,76 \times 10^{9} /$ л) та $\mathrm{Me}=0,76 \times 10^{9} /$ л $\left(\mathrm{Q} 25=0,57 \times 10^{9} /\right.$; $\mathrm{Q} 75=0,80 \times 10^{9} /$ л) відповідно $\mathrm{p}<0,05)$ й $\mathrm{Me}=23,50 \%(\mathrm{Q} 25=18,0 \%$; $\mathrm{Q} 75=28 \%)$ та $\mathrm{Me}=32 \%(\mathrm{Q} 25=30,0 \% ; \mathrm{Q} 75=33 \%)$ відповідно $\mathrm{p}<0,05)$. При цьому рівні загального кальцію сироватки крові у пацієнтів з фіброзом стулок аортального клапана були достовірно вищими (Ме=2,52 ммоль/л (Q25=1,96 ммоль/л; $\mathrm{Q} 75=2,60$ ммоль/л) та $\mathrm{Me}=2,36$ ммоль/л (Q25= 2,21 ммоль/л; Q75=2,57 ммоль/л) відповідно p<0,05). Отже, у дітей з ДАК за наявності фіброзу 
Огляди літератури, оригінальні дослідження, погляд на проблему, випадок з практики, короткі повідомлення стулок клапана мала місце відносно висока експресія гену NFATC1 при збільшенні абсолютного вмісту фракції CD25+ - інтерлейкін-2 рецепторонесучих активованих лімфоцитів та сироваткового кальцію, а також зменшення CD95+ субпопуляції Т-клітин.

При проведенні кореляційного аналізу у дітей з ДАК із фіброзом стулок була встановлена наявність позитивних кореляцій між діаметром кореня аорти та МШП $(R=0,60)$ й ЗСЛШ $(R=0,50)$, абсолютним та відносним рівнями $\mathrm{CD}_{25}$ лімфоцитів ( $R=0,50$ та $R=0,63$ відповідно), а також відносним та абсолютним рівнями $\mathrm{CD}^{+} 5^{+}$субпопуляції лімфоцитів ( $R=0,50$ та $\mathrm{R}=0,53$ відповідно). При цьому рівень відносної нормалізованої експресії гену NFATC1 у цих пацієнтів позитивно корелював із ЗСлШ $(\mathrm{R}=0,35)$ та рівнем сироваткового кальцію $(R=0,40)$ та негативно - із швидкістю кровотоку на аортальному клапані $(R=-0,30)$, а відносні рівні CD25+ та CD95+ субпопуляцій мали позитивний взаємозв'язок $(R=0,63)$.

У дітей з ДАК, що не мали фіброзу стулок клапана, діаметр кореня аорти мав позитивні кореляції з рівнем експресії гену $\operatorname{NFATC1}(\mathrm{R}=0,85)$, МШП $(R=0,31)$, зСлШ $(R=0,31)$, абсолютним та відносними рівнями $C D 25^{+}$лімфоцитів $(R=0,60$ та $R=0,82$ відповідно), відносним рівнем $\mathrm{CD}^{\circ} 5^{+}$Т-клітин $(\mathrm{R}=0,50)$, а також дві негативні кореляції з градієнтом тиску та швидкістю кровотоку на аортальному клапані ( $\mathrm{R}=-0,44$ та $\mathrm{R}=-0,41$ відповідно). У свою чергу, рівень експресії NFATC1 мав позитивні кореляції із швидкістю кровотоку на клапані $(\mathrm{R}=0,51)$, а також МШП та ЗСлШ $(\mathrm{R}=0,41$ та $\mathrm{R}=0,52$ відповідно).

Таким чином, у дітей з ДАК при наявності фіброзу стулок, при збереженні помірно збільшених волюметричних показників на аортальному клапані та збільшенні діаметра кореня аорти, найбільші зміни відбуваються за рахунок високої експресійної активності гену NFATC1, що супроводжується підвищенням абсолютної кількості NFATC1-асоційованої субпопуляції CD25+ - інтерлейкін-2 рецепторонесучих активованих лімфоцитів (також вищої стосовно референтних значень, 0,16-0,44×109/л), при зменшенні абсолютного та відносного рівнів $\mathrm{CD}^{\circ} 5^{+}$- апоптозрегулюючої субпопуляції цих клітин, та високих рівнях сироваткового кальцію, вищих за 2,50 ммоль/л. При цьому фіброз стулок у дітей з ДАК, на відміну від групи порівняння, з перебігом цієї вади без фібротичних змін на клапані, супроводжувався

зменшенням залежності діаметра кореня аорти від величини експресії NFATC1 та появою більш потужних його зв'язків з МШП та ЗСлШ, появою позитивних взаємозв'язків між експресією NFATC1 та рівнем сироваткового кальцію, а також між CD25+ та $\mathrm{CD}^{+} 5^{+}$субпопуляціями лімфоцитів. Встановлені факти щодо змін субпопуляційного складу лімфоцитів, кальцієвого обміну та високої експресії NFATC1 у дітей з ДАК при розвитку клапанного фіброзу, з одного боку, підтверджують описану в літературі протективну роль клітин імунної відповіді при патологічних змінах міокарда [10], а з іншого, свідчать про особливу роль цього гену у процесах транскрипційної регуляції морфогенетичної перебудови, що відбувається при розвитку фіброзу стулок. У зв'язку з цим, підвищена активність NFATC1 може бути розцінена як компенсаторна у відповідь на збільшення діаметра аорти, що супроводжує клапанний фіброз при ДАК з розвитком подальших ефектів гіперрегуляції у вигляді підвищення ітерлейкін-2-залежної фракції лімфоцитів та зниження активності апоптозу за рахунок відносного зменшення вмісту CD95+ їх субпопуляції. Сумація зазначених ефектів призводить також до активації NFATCзалежного сигнального шляху кальциневрину [15] та мобілізації кальцієвого обміну, що робить визначення експресії гену NFATC1 важливим діагностичним маркером при розвитку фіброзу стулок у дітей з ДАК.

Висновки. 1.У дітей з ДАК, що супроводжується фіброзом стулок аортального клапана, має місце розвиток початкової стадії аортопатії, що супроводжується збільшенням діаметра кореня аорти.

2. У дітей ДАК при розвитку фіброзу стулок аортального клапана має місце підвищена експресія гену NFATC1, а також абсолютного вмісту субпопуляції CD25+ - інтерлейкін-2 рецепторонесучих активованих лімфоцитів при зменшенні відносного та абсолютного вмісту апоптозрегулюючої CD95+ їх субпопуляції та збільшення рівня сироваткового кальцію.

3. Визначення експресії гену NFATC1 у дітей, що мають ДАК, є важливим діагностичним маркером розвитку фібротичних процесів на клапані та формування подальших серцевих ускладнень цієї вади.

Перспективи подальших досліджень полягають у створенні прогностичної математичної моделі розвитку фіброзу стулок аортального клапана у дітей з ДАК. 

ЛІТЕРАТУРА

1. Clinical and pathophysiological aspects of bicuspid aortic valve disease / M. W Pedersen, K. A. Groth, K. H. Mortensen [et al.] // Cardiology in the Young. - 2018. Vol. 29 (1). - P. 1-10.

2. Шарыкин А. С. Двустворчатый аортальный клапан у детей: малая аномалия или серьезный порок сердца? / А. С. Шарыкин // Consilium Medicum. Педиатрия (Прил.). - 2016. - Т. 3. - С. 99-102.

3. Girdauskas E. Bicuspid aortic valve and associated aortopathy: an update / E. Girdauskas, M. A. Borger // Semin Thorac. Cardiovasc. Surg. - 2013. - Vol. 25 (4). - P. 310-316.

4. Mart C. R. Shape of the dilated aorta in children with bicuspid aortic valve / C. R. Mart, B. E. McNerny // Ann. Pediatr. Cardiol. - 2013. - Vol. 6. - P. 126-631.

5. Aortic dilation in pediatric patients / Y. A. Zarate, E. Sellars, T. Lepard [et al.] // Eur. J. Pediatr. - 2015. Vol. 174. - P. 1585-1592.

6. Incidence, morphology, and progression of bicuspid aortic valve in pediatric and young adult subjects with coexisting congenital heart defects // T. Niaz, J. T. Poterucha, J. N. Johnson [et al.] // Congenit. Heart Dis. - 2017. Vol. 12. - P. 261-269.

7. Tripathi A. Population-based treated prevalence, risk factors, and outcomes of bicuspid aortic valve in a pediatric Medicaid cohort / A. Tripathi, Y. Wang, J. M. Jerell // Annals of Pediatric Cardiology. - 2018. - Vol. 11, Issue 2. - P. 119-124.

8. Bingruo Wu. Nfatc1 directs the endocardial progenitor cells to make heart valve primordium / Wu. Bingruo, H. S. Baldwin, B. Zhou // Trends in Cardiovascular Medicine. 2013. - Vol. 23, Issue 8. - P. 294-300.

9. The Syk-NFAT-IL-2 pathway in dendritic cells is required for optimal sterile immunity elicited by alum adju-

\section{REFERENCES}

1. Pedersen, M.W., Groth, K.A, Mortensen, K.H., Brodersen, J., Gravholt, C.H., \& Andersen, N.H. (2018). Clinical and pathophysiological aspects of bicuspid aortic valve disease. Cardiology in the Young, 29 (1), 1-10.

2. Sharykin, A.S. (2016). Dvustvorchatyy aortalnyy klapan u detey: Malaya anomaliya ili seryoznyy porok serdtsa? [Bicuspid aortic valve. Minor anomaly or the serious hart defect?] Consilium Medicum. Pediatriia (Pril.) - Consilium Medicum. Pediatrics (Apl.), 3, 99-102 [in Russian].

3. Girdauskas, E., \& Borger, M.A (2013). Bicuspid aortic valve and associated aortopathy: an update. Semin. Thorac. Cardiovasc. Surg., 25 (4), 310-316.

4. Mart, C.R, \& McNerny, B.E. (2013) Shape of the dilated aorta in children with bicuspid aortic valve. Ann. Pediatr. Cardiol., 6, 126-131.

5. Zarate, Y.A., Sellars, E., Lepard, T., Carlo, W.F., Tang X., \& Collins R.T. (2015). Aortic dilation in pediatric patients. Eur. J. Pediatr., 174, 1585-1592.

6. Niaz, T., Poterucha, J.T., Johnson, J.N., Craviari, C., Nienaber, T., \& Palfreeman, J. (2017). Incidence, morphology, and progression of bicuspid aortic valve in pediatric and young adult subjects with coexisting congenital heart defects. Congenit. Heart Dis., 12, 261-269.

7. Tripathi, A., Wang, Y., \& Jerell, J.M. (2018). Population-based treated prevalence, risk factors, and outcomes vants / H. J. Khameneh, A. W. Ho, R. Spreafico [et al.] // J. Immunol. - 2017. - Vol. 198. - P. 196-204.

10. Dysfunctional and proinflammatory regulatory T-lymphocytes are essential for adverse cardiac remodeling in ischemic cardiomyopathy / S. S Bansal, M. Goel, G. Zhou [et al.] // Circulation. - 2019. - Vol. 139 (2). P. 206-221.

11. Morphological features of uterine polyps in females of reproductive age / N. Ye. Gorban, T. D. Zadorozhna, I. B. Vovk, I.V. Zhulkevych // Вісник наукових досліджень. - 2019. - № 2. - C. 47-52.

12. The significance of aortic valve calcification in patients with bicuspid aortic valve disease / X. Ren, M. Zhang, K. Liu [et al.] // Int. J. Cardiovasc. Imaging. - 2016. Vol. 2 (3). - P. 471-478.

13. Kar P. Distinct Spatial Ca ${ }^{2+}$ Signatures Selectively Activate Different NFAT Transcription Factor Isoforms / P. Kar, A. B. Parekh // Mol. Cell. -2015. - Vol. 58. - P. 232-243.

14. Kamenshchyk A. V. Myocardial hypertrophy and intracardial hemodynamics in children with bicuspid aortic valve / A. V. Kamenshchyk, O. G. Ivanko // Патологія. 2017. - T. 14, № 2 (40). - C. 172-176.

15. Каменщик А. В. Експресія генів нуклеарного фактору активованих Т-клітин у дітей з двостулковим аортальним клапаном серця / А. В Каменщик, О. М. Камишний, О. Г. Іванько // Медичні перспективи. - 2016. T. XXI, № 3. - C. 29-34.

16. Translation of myocyte enhancer factor-2 is induced by hypertrophic stimuli in cardiomyocytes through a calcineurin-dependent pathway / J. Ye, M. Cardona, M. Llovera [et al.] // J. Mol. Cell. Cardiol. - 2012. - Vol. 53. P. 578-587.

of bicuspid aortic valve in a pediatric Medicaid cohort. Annals of Pediatric Cardiology, 11(2), 119-124.

8. Bingruo, Wu., Baldwin, H.S, \& Zhou, B. (2013). Nfatc1 directs the endocardial progenitor cells to make heart valve primordium. Trends in Cardiovascular Medicine, $23,8,294-300$.

9. Khameneh, H.J., Ho, A.W., Spreafico R., Derks, H., Quek, H.Q, \& Mortellaro, A. (2017). The Syk-NFAT-IL-2 pathway in dendritic cells is required for optimal sterile immunity elicited by alum adjuvants. J. Immunol., 198, 196-204.

10. Bansal, S.S, Goel, M., Zhou, G., Rokosh, G., Hamid, T., \& Prabhu, S.D. (2019). Dysfunctional and proinflammatory regulatory T-Lymphocytes are essential for adverse cardiac remodeling in ischemic cardiomyopathy. Circulation, 139 (2), 206-221.

11. Horban, N.Ye., Zadorozhna, T.D., Vovk, I.B, \& Zhulkevych, I.V. (2019). Morphological features of uterine polyps in females of reproductive age. Visnyk naukovykch doslidzhnen - Bulletin Scientific Research, 2, 47-52.

12. Ren, X., Zhang, M., Liu, K., Hou, Z., Gao, Y., Yin, W. \& Lu, B. (2016). The significance of aortic valve calcification in patients with bicuspid aortic valve disease. Int. J. Cardiovasc. Imaging, 32 (3), 471-478.

13. Signatures Selectively Activate Different NFAT Transcription Factor Isoforms, Mol. Cell, 58, 232-243. 
Огляди літератури, оригінальні дослідження, погляд на проблему, випадок з практики, короткі повідомлення

14. Kamenshchyk, A.V., \& Ivanko O.G. (2017). Myocardial hypertrophy and intracardial hemodynamics in children with bicuspid aortic valve. Patolohiia - Pathology, 14, 2 (40), 172-176.

15. Kamenshchyk, A.V., Kamyshnyi, A.M., \& Ivanko, O.H. (2016). Ekspresiia heniv nuklearnoho faktoru aktyvovanykh T-klityn u ditei z dvostulkovym aortalnym klapanom sertsia [Gene expression of nuclear factor of acti-

vated T-cells in children with bicuspid aortic valve]. Medychni perspektyvy - Medical Perspectives, 21, 3, 29-34 [in Ukrainian].

16. Cardona, Ye,J., Llovera, M., Comella, J.X., \& Sanchis, D. (2012). Translation of myocyte enhancer factor-2 is induced by hypertrophic stimuli in cardiomyocytes through a calcineurin-dependent pathway. J. Mol. Cell. Cardiol, 53, 578-587.

\title{
ЭКСПРЕССИЯ ГЕНА NFАТС1 У ДЕТЕЙ С ДВУСТВОРЧАТЫМ АОРТАЛЬНЫМ КЛАПАНОМ СЕРДЦА В ЗАВИСИМОСТИ ОТ НАЛИЧИЯ КЛАПАННОГО ФИБРОЗА
}

๑А. В. Каменщик

\author{
Запорожский государственный медицинский университет
}

РЕЗЮМЕ. Двухстворчатый аортальный клапан (ДАК) является частым врожденным пороком сердца, приводящим к развитию серьезных сердечных осложнений. Имеются сведения о протективной роли клеток иммунной системы при развитии фибротических процессов в миокарде. Гены семейства нуклеарного фактора активированных Т-клеток (NFATC), регулируя транскрипционные реакции путем активации Са-зависимого пути кальциневрина, участвуют как в вальвулогенезе, так и в иммунном ответе.

Цель - определение величины относительной нормализованной экспрессии NFATC1, параметров клеточного иммунитета, уровней сывороточного кальция при фиброзе створок аортального клапана у детей с ДАК и выявление взаимосвязей между указанными показателями.

Материал и методы. У 40 детей с ДАК, у 18 из которых имел место фиброз створок клапана аорты, определены параметры кровотока на клапане, диаметр корня аорты (Ао) и толщина задней стенки левого желудочка (ЗСЛЖ) и межжелудочковой перегородки (МЖП), уровень экспрессии NFATC1 (ехрNFATC1) методом экстракции PHK, абсолютное и относительное содержание CD95+ апоптозрегулирующей и CD25+-активированных интерлейкин-2 рецепторонесущей субпопуляции лимфоцитов методом моноклональных антител, а также сывороточного кальция (Са).

Результаты. У детей с ДАК при наличии фиброза створок клапана установлено достоверное повышение ехрNFATC1, увеличение Ao, Са, абсолютного содержания CD25+, уменьшение абсолютного и относительного содержания CD95+ субпопопуляций лимфоцитов. Установлены прямые корреляции между ехрNFATC1 и Ca, абсолютными значениями CD25+ и CD95 $5^{+}$Т-клеток, что свидетельствует о важной диагностической роли ехрNFATC1 при развитии фиброза клапана у этой категории пациентов.

КЛЮЧЕВЫЕ СЛОВА: двухстворчатый аортальный клапан; дети; фиброз створок; экпрессия гена NFATC1; кальций; клеточный иммунитет.

\section{NFATC1 GENE EXPRESSION IN CHILDREN WITH BICUSPID AORTIC VALVE OF THE HEART IN DEPENDENCE ON VALVULAR FIBROSIS EXISTENCE}

๑A. V. Kamenshchyk

\section{Zaporizhzhia State Medical University}

SUMMARY. Bicuspid aortic valve (BAV) is a common congenital heart disease leading to development of the serious heart complications. There is information about the protective role of immune system cells in development of myocardial fibrotic processes. The genes of the nuclear factor activated T-cells family (NFATC) regulating transcriptional reactions by activating the Ca-dependent calcineurin pathway and involves in both valvulogenesis and the immune response.

Material and Methods. In 40 children with BAV 18 of whom had fibrosis of the aortic valve leaflets, the parameters of blood flow on the valve, the diameter of the aortic root (Ao), the ventricular septum depth (VSd) and the left ventricle posterior wall depth (LVPWd), NFATC1 expression level (expNFATC1) by RNA extraction, the absolute and relative values of CD95+ apoptosis regulatory and CD25+ activated interleukin-2 receptor-bearing subpopulation of lymphocytes by monoclonal antibodies as well as serum calcium level (Ca) were detected.

Results. In children with BAV in valve leaflets fibrosis existence there are significant increase in expNFATC1, an increase in Ao, Ca, absolute CD25+ values, and decrease in the absolute and relative values of CD95+ lymphocyte subpopulations were found. Direct correlations were established between expNFATC1 and Ca, the absolute values of CD25+ and CD95+ T cells that is indicating an important diagnostic role of expNFATC1 in the development of valve fibrosis in this category of patients.

KEY WORDS: bicuspid aortic valve; children, leaflets fibrosis; NFATC1 gene expression; calcium; cellular immunity. 